\title{
DETERMINED CONSUMERS ONLINE PURCHASE INTENTION FACTORS BY CONSIDERING RISK AND E-TRUST
}

\author{
${ }^{1}$ Aulia F. Hadining, ${ }^{2}$ Salmah Ayu Haryanti, ${ }^{3}$ Tazkia Rasyid Munajat \\ ${ }^{1}$ Industrial Engineering Department, Faculty of Engineering Universitas Singaperbangsa Karawang \\ Email : aulia.fasha@gmail.com \\ ${ }^{2}$ Industrial Engineering Department, Faculty of Engineering Universitas Singaperbangsa Karawang \\ ${ }^{3}$ Industrial Engineering Department, Faculty of Engineering Universitas Singaperbangsa Karawang
}

Masuk : 01-07-2020, revisi: 06-07-2020, diterima untuk diterbitkan :07-07-2020

\begin{abstract}
ABSTRAK
Niat pembeli adalah salah satu pendorong utama bagi pembeli untuk melakukan transaksi pembayaran dan akhirnya membeli produk atau layanan. Semakin tinggi niat beli, semakin besar keinginan individu untuk membeli barang. Ini juga berlaku untuk pembelian online menggunakan e-commerce. Transaksi pembelian online memiliki karakteristik bahwa tidak ada interaksi fisik antara pembeli, penjual, dan proses pembayaran. Niat pembelian online dapat dipengaruhi oleh berbagai faktor. Berdasarkan studi sebelumnya, faktor-faktor penting dalam pembelian online adalah faktor pengalaman berbelanja, risiko yang mungkin, dan kepercayaan pada situs web penyedia layanan e-commerce. Penelitian ini bertujuan untuk mengetahui faktor-faktor yang berpengaruh dalam niat pembelian online dengan membangun model penelitian. Model dalam penelitian ini adalah kombinasi variabel penelitian dari penelitian sebelumnya. Ada tujuh variabel penelitian dengan sepuluh hipotesis penelitian. Variabel yang digunakan untuk menyusun model penelitian adalah Pengalaman Belanja Online, Kualitas Web, Risiko Produk, Risiko Keuangan, Risiko Privasi, E-Trust, dan Niat Pembelian Online. Tahap selanjutnya dari penelitian ini adalah melakukan survei penelitian dan mengolah hasil data menggunakan SMART PLS 3.0.
\end{abstract}

Kata Kunci: E-commerce, E-Trust, pembelian online, resiko, kualitas situs

\begin{abstract}
The buyer's intention is one of the main drivers for a buyer to make payment transactions and end up buying products or services. The higher the purchase intentions, the greater the willingness of the individual to buy the goods. This also applies to online purchases using e-commerce. Online purchase transactions have the characteristic that there is no physical interaction between the buyer, seller, and payment process. The online purchase intention can be influenced by various factors. Based on previous studies, important factors in online purchasing are shopping experience factors, possible risks, and trust in e-commerce service provider websites. This study aims to determine the influential factors in online purchase intention by building a research model. The model in this study is a combination of research variables from previous studies. There are seven research variables with ten research hypotheses. The variables used to compile the research model are Online Shopping Experience, Web Quality, Product Risk, Financial Risk, Privacy Risk, E-Trust, and Online Purchase Intention. The next stage of this research is to conduct a research survey and processing the results of data using SMART PLS 3.0.
\end{abstract}

Keywords: Online Purchasing, E-Commerce, Risk, E-Trust, Websites Quality

\section{INTRODUCTION}

The internet has not only became a media for communicating and searching for information but also for purchasing goods through e-commerce. According to Statista in Cortinas et,al online sales increased by $24.8 \%$ and involved $10.2 \%$ of total sales worldwide. By the development of the internet, the commodity of online sales is very diverse, even consumers are able to purchase health goods online. Therefore, consumers must have trust in products purchased online. The growth of online trade transactions (e-commerce) in Indonesia has not been in line with consumer trust. The study revealed that performance, psychological, company financial, and online payment risks have a negative influence on purchase intention. Thus, perception of risk has a negative influence on consumer trust that affect online purchase intention. In e-commerce, consumer trust is defined as consumer expectation to service providers that able to be trusted or relied upon to fulfill their promises. It is important for the consumers to intend to visit the 
seller's website to obtain information so that they are able to complete a transaction by purchasing a product or service in order to increase e-commerce acceptance.

Previous research revealed that there were some variables influencing online purcase intention, such as consumer behavior, internet shopping experience, purchase intention, consumer characteristics, purchasing environtment, and consumer conduct. Purchase intention is one of the main drivers for a buyer to tend to continue payment transactions and end with buying a product or service. The greater the purchase intention, the greater the individual's willingness to buy goods. According to Mohseni et, al., purchase attention is influenced by web brand, personal value, shopping experience, and risk perception. Purchase intention is induced by various factors such as trust, website, shopping experience, and risk perception. The purpose of this study is to build a model that can be used to determine the influential factors on purchase intention through e-commerce.

\section{Model Development}

Dai et, al., investigated the factors of online shopping experience and the dimensions of risk perception such as product, financial, and privacy risk in determining their effects on online purchase intention. Wang et, al. stated that online purchase intention arises due to consumers etrust on website quality. This study combines models from Dai dkk. and Wang dkk., to observe the effect of online shopping experience, website quality, product risk, financial risk, privacy risk, and e-trust on online purchase intention through e-commerce.

According to Forsythe and Shi (2003) in Dai dkk., online shopping experience influences personal perception who like online shopping and has intention to do online shopping so that they are able to reduce the risks. Online shopping experience is independent variable that affects perceived risk dimensions:

H1: Online shopping experience has a negative effect on product risk

$\mathrm{H} 2$ : Online shopping experience has a negative effect on financial risk

H3: Online shopping experience has a negative effect on privacy risk

Study conducted by Wang revealed that e-trust has a positive effect. Website quality is independent variable that affects e-trust

H4: Website quality has a positive effect on e-trust

According to Forsyte and Shi in Dai dkk., consumers accept product risk when the price offered on the website is higher but product information listed on the website is limited. Therefore, consumers find it difficult to judge the quality product. Thus, it affects consumer intending to shop online. According to the explanation, it can be concluded that:

H5: Product risk has a negative effect on online purchase intention

According to Arrifin dkk., financial risk is defined as the probability of an internet shopper suffering monetary losses from purchasing that did not performing well or not commensurate with the price paid. Masoud revealed that financial risk such as fear of losing money and the possibility of sellers will disclose or disseminate consumer credit card information has a negative effect on online shopping behavior. Therefore, it can be concluded that:

H6: Financial risk has a negative effect on online purcase intention

Naiyi revealed that privacy risk is risk associated with consumers' personal information security such as address, email, telephone, and credit card number. Garbarino and Strahilevitz (2004) in Dai dkk defined privacy risk as possible disclosure of buyer's personal information when making an online purchasing. It can be concluded that: 
H7: Privacy risk has a negative effect on online purchase intention

Online transactions are transactions that do not involve face-to-face between producers and consumers. Trust factor (e-trust) is the key factor of many factors that affect shopping online transactions. An e-commerce must create a good web quality in order to build consumers' e-trust so that intention to buy in the site can appear.

H8: E-trust has a positive effect on online purchase intention

Having a successful online shopping experience before can affect future online purchasing intention significantly. Corbin et.al (2003) in Mohseni et.al (2016) investigated the key factors that affect consumers trust on e-commerce. Corbin stated that people who have high trust and good experience on e-commerce may have high intention on doing online purchasing through ecommerce. It can be concluded that:

H9: Online shopping experience has a positive effect on online purchase intention

Web quality is the factor that able to affect consumers' intention to do purchasing through the site. System, information, and service quality significantly affect the transaction intention on mobile shopping.

H10: Website quality has a positive effect on online purchase intention

Figure 1 shows a model proposed in this study:

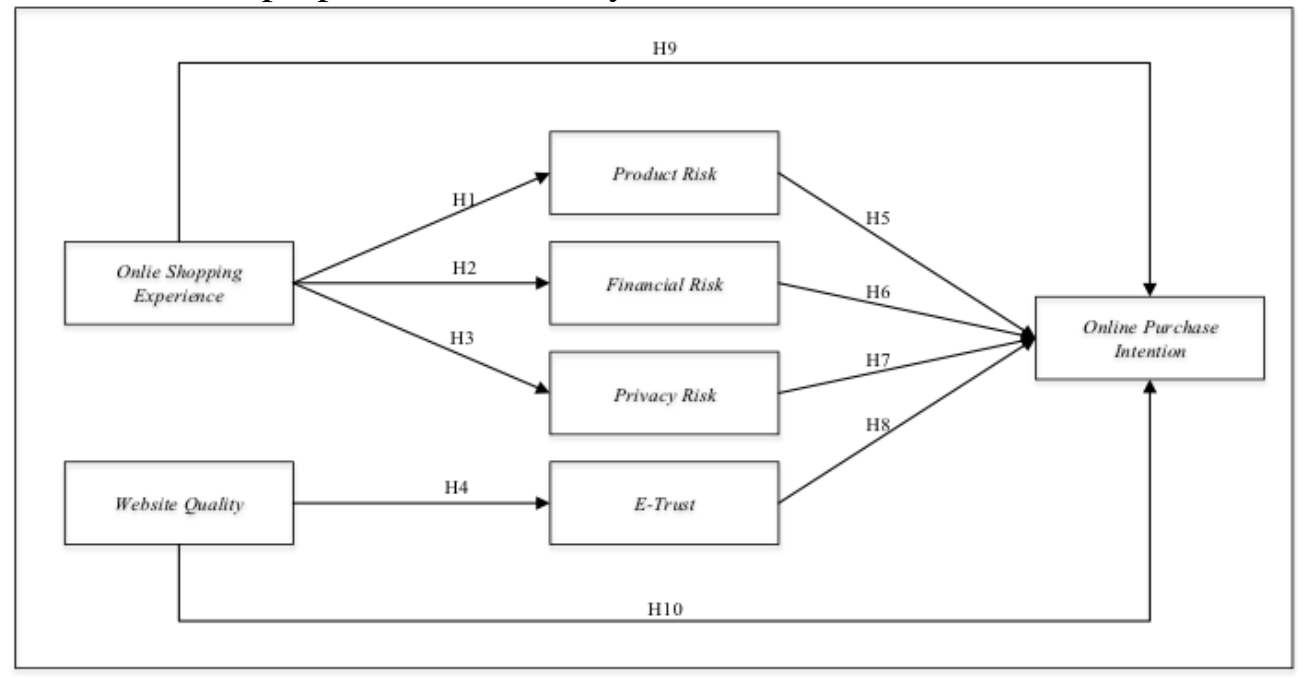

Figure 1. Research Model

\section{RESEARCH METHODOLOGY}

This study explains factors model development that affects online purchase intention through The model developed in this study was taken from previous literature to data collection stage. A total of 10 hypotheses were used in this study which consisted of several research variables in the model. Data collection is done by distributing questionnaires, where each variable in each model is represented by several indicators. The data that has been obtained in this study is processed quantitatively using the Structural Equation Modeling (SEM) method with the Partial Least Square (PLS) model. The research sample is calculated by using a purposive sampling method to adjust the research objectives. The sample used in this study was 100 respondents. Respondents are workers in the Karawang area, then the questionnaire would be distributed to workers in the Karawang area. This study has 7 research variables, including Online Shopping Experience, Website Quality, Product Risk, Financial Risk, Privacy Risk, e-Trust, and Online Purchase Intention. Each variable is represented by several indicators. The total indicators used 
in this study were 39 indicators. These indicators are statements that are measured using a Likert scale with a range of values $1-5(1=$ strongly disagree to $5=$ strongly agree $)$. This study aims to determine the factors that influence online purchase intention.

\section{RESULT AND DISCUSSION}

\section{Measurement Model Evaluation}

Stage of measurement model evaluation is a stage used in conducting validity test and reliability of a construct. Validity test consists of 2 stages which are convergent validity and discriminant validity. Convergent validity is assessed based on the loading value on each indicator. The recommended loading value is more than 0.7 , but loading values at the limit of 0.5 to 0.6 are still allowed. The indicators and loading values retained in this study have met the values of 0.7 or 0.5 to 0.6 (Figure 2). Convergent validity is also measured based on the AVE value. The model can be considered good if the AVE value is above 0.5. Table 1 shows that the AVE value has exceeded 0.5. Furthermore, discriminant validity is seen based on the value of the Heterotrait Monotrait (HTMT). The HTMT treshold value for each variable is below 0.90. Based on Table 2 , it can be seen that the HTMT value has met the requirements. Thus, the discriminant validity has been fulfilled. Reliability test using the PLS method is seen based on the value of Cronbach's alpha and composite reliability. A construct can be said to be reliable if it has a Cronbach's alpha value and composite reliability above 0.7 . Based on Table 1, it can be said that the construct has met the reliability test or has been reliable.

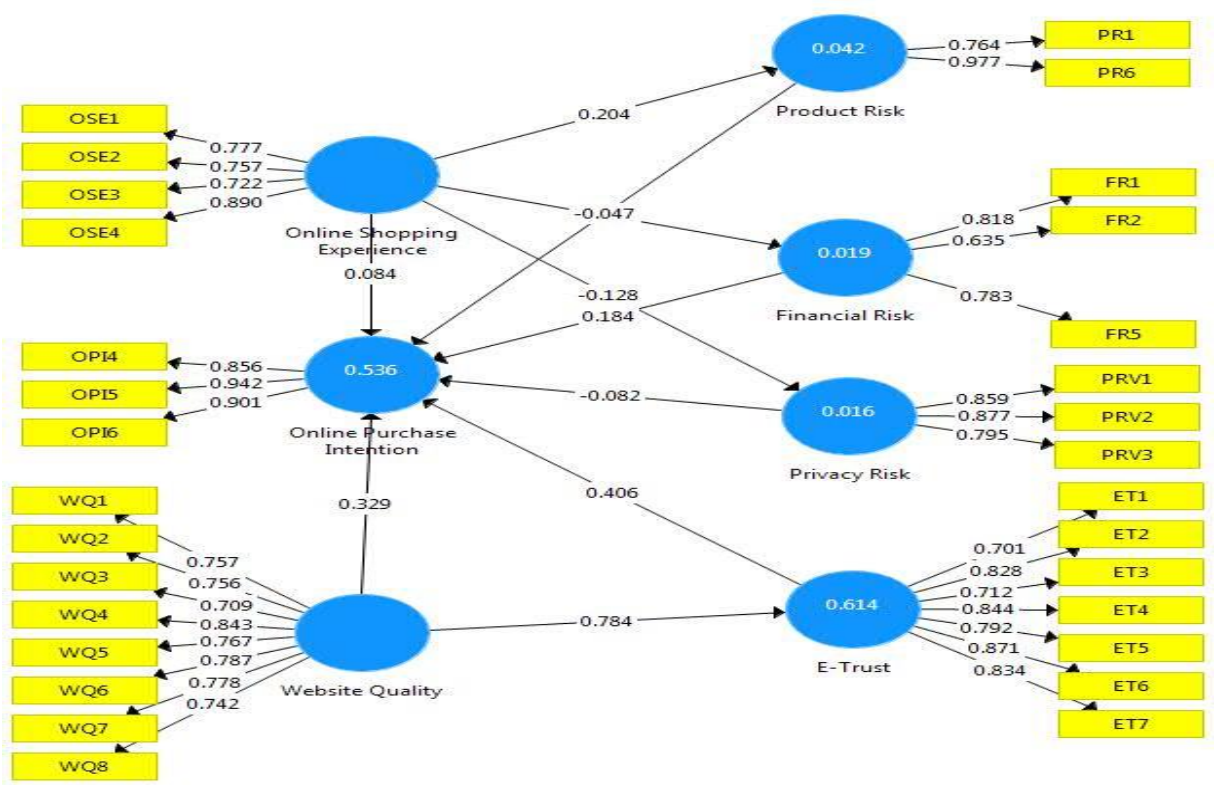

Figure 2. Outer loading

Table 1. AVE, cronbach's alpha, composite reliability

\begin{tabular}{lccc}
\hline \multicolumn{1}{c}{ Latent Variable } & AVE & $\begin{array}{c}\text { Cronbach's } \\
\text { Alpha }\end{array}$ & $\begin{array}{c}\text { Composite } \\
\text { Reliability }\end{array}$ \\
\hline $\begin{array}{l}\text { Online Shopping Experience } \\
\text { (OSE) }\end{array}$ & 0,623 & 0,822 & 0,868 \\
Website Quality (WQ) & 0,590 & 0,901 & 0,920 \\
Product Risk (PR) & 0,769 & 0,757 & 0,868 \\
Financial Risk (FR) & 0,562 & 0,672 & 0,792 \\
Privacy Risk (PRV) & 0,712 & 0,800 & 0,881 \\
E-Trust (ET) & 0,640 & 0,905 & 0,925 \\
\hline
\end{tabular}




\begin{tabular}{llll}
\hline $\begin{array}{l}\text { Online Purchase Intention } \\
\text { (OPI) }\end{array}$ & 0,811 & 0,883 & 0,928 \\
\hline
\end{tabular}

Table 2. Discriminant validity (Heterotrait-Monotrait)

\begin{tabular}{lccccccc}
\hline & ET & FR & OPI & OSE & PR & PR & WQ \\
\hline E-Trust & & & & & & & \\
Financial Risk & 0,113 & & & & & & \\
Online Purchase Intention & 0,746 & 0,233 & & & & & \\
Online Shopping Experience & 0,152 & 0,198 & 0,162 & & & & \\
Privacy Risk & 0,091 & 0,678 & 0,072 & 0,186 & & & \\
Product Risk & 0,228 & 0,608 & 0,17 & 0,18 & 0,231 & & \\
Website Quality & 0,858 & 0,252 & 0,745 & 0,141 & 0,14 & 0,186 & \\
\hline
\end{tabular}

\section{Structural Model Evaluation}

Structural model evaluation is assessed based on value of R-Square, Q-Square predictive relevance, and path coefficient. R-Square values indicate variability for each endogenous variable produced by other variables. Table 3 shows the R-Square values for each study variable.

Table 3. Structural model measurement

\begin{tabular}{lcc}
\hline \multicolumn{1}{c}{ Variabel } & R-Square & Q-Square \\
\hline E-Trust & 0,614 & 0,360 \\
Financial Risk & 0,019 & 0,004 \\
Online Shopping Experience & - & - \\
Online Purchase Intention & 0,536 & 0,383 \\
Privacy Risk & 0,016 & 0,004 \\
Product Risk & 0,042 & 0,014 \\
Website Quality & - & - \\
\hline
\end{tabular}

Based on the results of the r-square values in Table 3, it can be concluded that:

1. Variable of online shopping experience reveals $4.2 \%$ variance in the product risk variable, $1.9 \%$ variance in the financial risk variable, and $1.6 \%$ variance in the privacy risk variable.

2. The website quality variable shows $61.4 \%$ of the variance in the e-trust variable

3. The e-trust, product risk, financial risk, and privacy risk variables show $53.6 \%$ of the variance in the online purchase intention variable.

Other structural model measurement is by seeing value of Q-Square predictive relevance. Qsquare assessing how well the value of observations produced by the model and its estimated parameters. A model can be considered to have a good predictive relevance value if the QSquare value is more than 0. Based on the results of the Q-Square values presented in Table 3, the model is considered to have had a good predictive relevance. Furthermore, in this research, there were 3 hypotheses that were accepted. A hypothesis can be accepted if it had a $t$-value> 1.96 and $p$-value $<0.05$. Table 4 shows the results of the hypothesis of this study.

Table 4. Hypothesis testing result

\begin{tabular}{cccccc}
\hline Hipotesis & Path & $\begin{array}{c}\text { Original } \\
\text { Sample }\end{array}$ & $\begin{array}{c}\text { T- } \\
\text { values }\end{array}$ & $\begin{array}{c}\text { P- } \\
\text { values }\end{array}$ & Result \\
\hline $\mathrm{H} 1$ & OSE $\rightarrow$ PR & 0,204 & 1,591 & 0,112 & Rejected \\
$\mathrm{H} 2$ & OSE $\rightarrow$ FR & $-0,138$ & 0,723 & 0,470 & Rejected \\
$\mathrm{H} 3$ & OSE $\rightarrow$ & $-0,128$ & 0,673 & 0,501 & Rejected
\end{tabular}




\begin{tabular}{cccccc}
\multicolumn{7}{c}{ PRV } & & & & \\
H4 & WQ $\rightarrow$ ET & 0,784 & 21,508 & 0,000 & Accepted \\
H5 & PR $\rightarrow$ OPI & $-0,047$ & 0,572 & 0,567 & Rejected \\
H6 & FR $\rightarrow$ OPI & 0,184 & 1,544 & 0,123 & Rejected \\
& PRV $\rightarrow$ & & & & \\
H7 & OPI & $-0,082$ & 0,61 & 0,542 & Rejected \\
H8 & ET $\rightarrow$ OPI & 0,406 & 2,902 & 0,004 & Accepted \\
& OSE $\rightarrow$ & & & & \\
H9 & OPI & 0,084 & 0,923 & 0,357 & Rejected \\
H10 & WQ $\rightarrow$ OPI & 0,329 & 2,336 & 0,020 & Accepted \\
\hline
\end{tabular}

This research aimed to find out affecting factors toward online purchase intention of customer by considering risk factors and e-trust. From 10 hypotheses proposed in this research, there were 3 hypotheses which had a significant influence. Based on the online shopping experience variable that affected the dimensions of risk perception such as product risk, financial risk, and privacy risk, the results obtained are that online shopping experience had no negative effect on product risk, financial risk, and privacy risk $(\mathrm{H} 1, \mathrm{H} 2$, and $\mathrm{H} 3$ were rejected). This proves that one's experience in shopping online does not affect individual's perception of product risk, financial risk and privacy risk. The more experienced someone in doing shopping online does not guarantee that the risks to the product, financial, and privacy can be reduced. Otherwise, if an Individual does not have experience in doing online shopping, the consumer may not necessarily have the perception that online shopping will provide risks in terms of product, financial, and privacy. Based on website quality variables that affect e-trust, the results obtained are website quality that has a positive influence on e-trust (H4 was accepted). This is in line with previous research which states that website quality has an influence on e-trust. It can be concluded that the better the quality of online shopping websites, the higher the level of trust (e-trust) of individual in conducting online shopping.

Based on the variables which affected online purchase intention in terms of risk, variable product risk, financial risk, and privacy risk do not negatively affect online purchase intention so H5, H6, and $\mathrm{H} 7$ were rejected. This indicates that online shopping users in the Karawang area are not currently paying much attention to the issue of risk in shopping online. The greater or lower the level of risk, does not affect an individual's intention in making purchases online. The E-Trust variable had a positive effect on online purchase intention (H8 accepted). An individual level of confidence in doing online shopping has an impact on their intention to make purchases through purchases. The higher the trust, the higher the person's intention to do online shopping. This is in line with the influence of website quality on online purchase intention. In this research, website quality had a positive effect on online purchase intention (H10 received). The better the quality of websites provided by online shopping sites, the higher online shopping intentions can be. An individual's shopping experience does not have a positive effect on online purchase intention (H9 was rejected). An individual's high online shopping experience does not guarantee that their purchase intention online will also be high.

\section{Managerial Implication}

Implication of result of the research emphasizes in the real benefit of research's result to encourage consumer's intention to make online purchases. The results of this research are useful for companies engaged in e-commerce to determine the right strategy in marketing. In this research, website quality variables had an influence on online purchase intention. This indicates that the quality of websites offered by several online shopping sites is able to convince 
consumers to be able to shop online through these sites. The ease, convenience, and attractive features offered by several online shopping sites can increase the confidence of its consumers. Thus, they have high intentions in doing online shopping. Online shopping site service providers must continue to improve the quality of their website so that these users have the confidence to continue to make online purchases through the site. In terms of risk, service providers must also continue to improve security in online shopping so consumers do not have a negative perception of online shopping.

\section{CONCLUSION AND SUGGESTIONS}

According to the research which has been conducted toward online purchase intention by considering risk factors and e-trust, it can be concluded that website quality, and e-trust have a direct influence on online purchase intention. The influence of website quality on online purchase intention is $32.9 \%$, whereas e-trust has an influence on online purchase intention of $40.6 \%$. Factors of online shopping experience, product risk, financial risk, and privacy risk do not have a direct influence on online purchase intention.

\section{REFERENCES}

M. Cortinas, R. Cabeza, R. Chocarro, and A. Villanueva, "Attention to online channels across the path to purchase: An eye-tracking study," Electronic Commerce Research and Applications, vol. 36, 2019, doi: doi.org/10.1016/j.elerap.2019.100864.

W.-I. Lee, S.-Y. Cheng, and Y.-T. Shih, "Effects among product attributes, involvement, wordof-mouth, and purchase intention in online shopping," Asia Pacific Management Review, vol. 22, no. 4, pp. 223-229, 2017, doi: doi.org/10.1016/j.apmrv.2017.07.007.

I. B. Hong and H. S. Cha, "The mediating role of consumer trust in an online merchant in predicting purchase intention," International Journal of Information Management, vol. 33, no. 6, pp. 927-939, 2013, doi: doi.org/10.1016/j.ijinfomgt.2013.08.007.

H. Siagian and E. Cahyono, "ANALISIS WEBSITE QUALITY, TRUST DAN LOYALTY PELANGGAN ONLINE SHOP," Jurnal Manajemen Pemasaran, vol. 8, no. 2, pp. 5561, 2014, doi: https://doi.org/10.9744/pemasaran.8.2.55-61.

B. Ganguly, S. B. Dash, D. Cyr, and M. Head, "The effects of website design on purchase intention in online shopping: The mediating role of trust and the moderating role of culture," International Journal of Electronic Business vol. 8, no. 4, pp. 302-330, 2010, doi: DOI: 10.1504/IJEB.2010.035289.

H. Amadea, Keni, and L. Soelaiman, "Pengaruh Past Experience dan Perceived Risk Terhadap Purchase Intention Pada Situs Rakuten.co.id Di Jakarta Dengan Customer Trust Sebagai Variabel Moderator," in Conference on Management and Behavioral Studies, Jakarta, 2016: Universitas Tarumanagara.

H. K. Chi, H. R. Yeh, and Y. T. Yang, "The Impact of Brand Awareness on Consumer Purchase Intention: The Mediating Effect of Perceived Quality and Brand Loyalty," Journal of International Management Studies, vol. 4, pp. 135-144, 2009.

S. Mohseni, S. Jayashree, S. Rezaei, A. Kasim, and F. Okumus, "Attracting tourists to travel companies' websites: the structural relationship between website brand, personal value, shopping experience, perceived risk and purchase intention," Current Issues in Tourism, vol. 21, no. 6, pp. 616-645, 2016, doi: 10.1080/13683500.2016.1200539.

B. Dai, S. Forsythe, and W.-S. Kwon, "The Impact Of Online Shopping Experience On Risk Perceptions And Online Purchase Intentions: Does Product Category Matter?," Journal of Electronic Commerce Research, vol. 15, no. 1, pp. 13-24, 2014. 
L. Wang, R. Law, B. D. Guillet, K. Hung, and D. K. C. Fong, "Impact of Hotel Website Quality on Online Booking Intentions: eTrust as a Mediator," International Journal of Hospitality Management, vol. 47, pp. 108-115, 2015, doi: https://doi.org/10.1016/j.ijhm.2015.03.012.

S. K. Ariffin, T. Mohan, and Y.-N. Goh, "Influence of consumers' perceived risk on consumers' online purchase intention," Journal of Research in Interactive Marketing, vol. 12, no. 2, 2018, doi: DOI: 10.1108/JRIM-11-2017-0100.

E. Y. Masoud, "The Effect of Perceived Risk on Online Shopping in Jordan," European Journal of Business and Management, vol. 5, no. 6, 2013.

Y. Naiyi, "Dimensions of Consumer's Perceived Risk in Online Shopping " Journal of Electronic Science and Technology of China, vol. 2, no. 3, pp. 177-182, 2004.

S. C. Chen and G. S. Dhillon, "Interpreting Dimensions of Consumer Trust in E-Commerce," Information Technology and Management, vol. 4, no. 2-3, pp. 303-318, 2003, doi: https://doi.org/10.1023/A:1022962631249.

I. Ghozali, Structural Equation Modeling Metode Alternatif Dengan Partial Least Square, 2 ed. Semarang: Universitas Diponegoro, 2014.

J. Henseler, C. M. Ringle, and M. Sarstedt, "A new criterion for assessing discriminant validity in variance-based structural equation modeling," J. of the Acad. Mark. Sci, vol. 43, pp. 115-135, 2015, doi: 10.1007/s11747-014-0403-8. 